\title{
Effects of Light-Emitting Diodes on the Accumulation of Glucosinolates and Phenolic Compounds in Sprouting Canola (Brassica napus L.)
}

\author{
Chang Ha Park ${ }^{1,+}{ }^{\dagger}$ Nam Su Kim ${ }^{1, \dagger}$, Jong Seok Park ${ }^{2}$, Sook Young Lee ${ }^{3}$, Jong-Won Lee ${ }^{4, *}$ (D) and \\ Sang Un Park ${ }^{1, *}$ \\ 1 Department of Crop Science, Chungnam National University, 99 Daehak-ro, Yuseong-gu, \\ Daejeon 34134, Korea; parkch804@gmail.com (C.H.P.); kns917555@naver.com (N.S.K.) \\ 2 Department of Horticultural Science, Chungnam National University, 99 Daehak-ro, Yuseong-gu, \\ Daejeon 34134, Korea; jongseok@cnu.ac.kr \\ 3 Marine Bio Research Center, Chosun University, 61-220 Myeongsasimni, Sinji-myeon, Wando-gun, \\ Jeollanamdo 59146, Korea; seedbank@chosun.ac.kr \\ 4 Department of Horticulture Environment System, Korea National College of Agriculture and Fisheries, 1515, \\ Kongjwipatjwi-ro, Deokjin-gu, Jeonju-si, Jeollabuk-do 54874, Korea \\ * Correspondence: leewon1@korea.kr (J.-W.L.); supark@cnu.ac.kr (S.U.P.); Tel.: +82-63-238-9155 (J.-W.L.); \\ +82-42-821-6730 (S.U.P.); Fax: +82-63-238-9140 (J.-W.L.); +82-42-822-2631 (S.U.P.) \\ + These authors contributed equally to this work.
}

Received: 25 January 2019; Accepted: 12 February 2019; Published: 19 February 2019

check for updates

\begin{abstract}
In this study, we investigated optimal light conditions for enhancement of the growth and accumulation of glucosinolates and phenolics in the sprouts of canola (Brassica napus L.). We found that the shoot lengths and fresh weights of red light-irradiated sprouts were higher than those of sprouts exposed to white, blue, and blue + red light, whereas root length was not notably different among red, blue, white, and blue + red light treatments. The accumulations of total glucosinolates in plants irradiated with white, blue, and red lights were not significantly different (19.32 \pm 0.13 , $20.69 \pm 0.05$, and $20.65 \pm 1.70 \mathrm{mg} / \mathrm{g}$ dry weight (wt.), respectively). However, sprouts exposed to blue + red light contained the lowest levels of total glucosinolates (17.08 $\pm 0.28 \mathrm{mg} / \mathrm{g}$ dry wt.). The accumulation of total phenolic compounds was the highest in plants irradiated with blue light ( $3.81 \pm 0.08 \mathrm{mg} / \mathrm{g}$ dry wt.), 1.33 times higher than the lowest level in plants irradiated with red light ( $2.87 \pm 0.05 \mathrm{mg} / \mathrm{g}$ dry wt.). These results demonstrate that red light-emitting diode (LED) light is suitable for sprout growth and that blue LED light is effective in increasing the accumulation of glucosinolates and phenolics in B. napus sprouts.
\end{abstract}

Keywords: light-emitting diode; sprouting canola; sprouts; secondary metabolites

\section{Introduction}

Plant sprouts, defined as young shoots formed from seeds, have been recognized as outstanding sources of essential and non-essential nutrients such as carbohydrates, proteins, minerals, and vitamins. Furthermore, sprouts can aid in the prevention of diverse diseases due to their biological activities (antioxidant, anticancer, antigenotoxic, and antibiotic effects), which are associated with health-maintaining compounds (glucosinolates, polyphenols, terpenes, sterols, and vitamins) [1,2]. A previous study reported that plant sprouts have considerably higher levels of certain health-protecting phytochemicals than those discovered in the mature plant [3]. In particular, Brassica sprouts have been consumed as raw materials and provide a variety of bioactive compounds 
(glucosinolates, isothiocyanates, polyphenols, anthocyanins, and carotenoids) that can contribute to the prevention and treatment of diseases [1,2,4-8].

Canola (Brassica napus), belonging to the Brassicaceae family, has been cultivated and harvested worldwide for its seeds, which can be used as a source of provender, an appetizing vegetable oil, and biodiesel $[9,10]$. Previous studies have reported that the seeds of canola varieties contain various hydroxycinnamic acid derivatives ( $p$-coumaric, caffeic, ferulic, and sinapic acids) and that the leaves of canola contain benzoic acid derivatives (gentisic, p-hydroxybenzoic, protocatechuic, syringic, and vanillic acids). In particular, sinapic derivatives are dominant phenolic compounds in these seeds [2,11,12]. Glucosinolates are sulfur-containing bioactive compounds present in Brassica vegetables. Brown and Morra [13], Vierheilig et al. [14], and Yasumoto et al. [15] detected six glucosinolates (progoitrin, gluconapin, 4-hydroxyglucobrassicin, glucobrassicanapin, glucobrassicin, and gluconasturtiin) in Brassica vegetables, whereas Yasumoto et al. [15] reported differences in six glucosinolates in different organs of canola cv. Kirariboshi sprouts.

Glucosinolates, which contain nitrogen and sulfur structures, are a group of secondary metabolites in the Cruciferae family and can be classified into three classes (aliphatic, aromatic, and indolic glucosinolates) [16]. Recently, interest in glucosinolates has increased owing to the biocidal [17] and cancer chemopreventive activity [18] of their hydrolysis products (isothiocyanates, nitriles, thiocyanates, epithionitriles, and oxazolidines). In particular, intake of isothiocyanates from Brassica vegetables has been shown to reduce cancer risk $[19,20]$.

Plant phenolic compounds are secondary metabolites ubiquitous in most higher plants and responsible for plant defense against biotic and abiotic stresses (pathogen and insect attack, excess light and ultraviolet radiation, extreme temperature, wounding, and nutrient deficiencies) [21,22]. Furthermore, dietary phenolic compounds in plant-based foods may be beneficial to human health, since such compounds have anti-human immunodeficiency virus (HIV) [21,23], antioxidant [21,24], anticancer [21,25], anti-inflammatory [21,26], anticariogenic [21,27], and cardioprotective $[21,28]$ properties.

Light quality and intensity are crucial for plant development, morphogenesis, growth, and pigment biosynthesis [29]. Light-emitting diodes have been successfully applied to control plant growth environments due to their advantages of high-efficiency energy conversion, long lifetime, wavelength specificity, small bandwidth and volume, controllable light quality and intensity, and low-grade thermal energy output [30]. In particular, LED lights have more specific wavelengths and smaller bandwidths compared with filters and can provide a wide range of light sources for plant growth [31].

To our knowledge, there have been no previous studies on the effects of different LED light sources on secondary metabolites in B. napus sprouts. Therefore, the purpose of the present study was to investigate the effects of different LED light wavelengths (blue + red $(470$ and $660 \mathrm{~nm}$ ) blue $(470 \mathrm{~nm})$, red $(660 \mathrm{~nm})$, or white $(380 \mathrm{~nm}))$ on the growth and production of glucosinolates and phenolic compounds in B. napus sprouts.

\section{Materials and Methods}

\subsection{Plant Samples}

Seeds of canola were obtained from Asia Seed Co., Ltd (Seoul, Korea). The seeds were soaked into tap water for 1 day, and thereafter 200 seeds were placed in plastic pots containing vermiculite soil and watered with $100 \mathrm{~mL}$ of tap water. Each pot was then transferred to an incubator equipped with white (wavelength, $380 \mathrm{~nm}$ ), blue (wavelength, $470 \mathrm{~nm}$ ), red (wavelength, $660 \mathrm{~nm}$ ), or blue + red LEDs. Specifically, the white, red, and blue components of the LED grow light (PARUS LED Co., Cheoan, Korea) contain 14 pieces of LED, respectively. The plant growth chamber was equipped with two LED grow lights for the white, red, and blue LED treatments. On the other hand, for the blue + red treatment, the chamber was equipped with a blue and a red LED grow light, respectively. The seeds 
were germinated and grown under a 16-h photoperiod with high-intensity irradiation (flux rate of $50 \mu \mathrm{mol} / \mathrm{s} \cdot \mathrm{m}^{2}$ ) at $25{ }^{\circ} \mathrm{C}$. After 14 days, shoot length, root length, and fresh weight were measured and the plant tissues were harvested in liquid nitrogen. The frozen samples were then lyophilized and ground to fine powders for further HPLC analysis.

\subsection{Extraction of Glucosinolates from Brassica napus and HPLC Analysis}

Glucosinolate extraction and desulfation were performed using previously described procedures [32-34]. In brief, a mini-column, packed with DEAE-Sephadex A- $25\left(\mathrm{H}^{+}\right.$form by $0.5 \mathrm{M}$ sodium acetate, approximately $40 \mathrm{mg}$ dry wt.), was prepared for glucosinolate extraction. Methanol (MeOH: $70 \% \mathrm{v} / \mathrm{v}$ ) was boiled to $70^{\circ} \mathrm{C}$ and $1.5 \mathrm{ml}$ of the boiled $\mathrm{MeOH}$ was placed in a tube containing $100 \mathrm{mg}$ of dried sprout powder. The mixture was incubated in a water bath at $70{ }^{\circ} \mathrm{C}$ for $5 \mathrm{~min}$ for endomyrosinase inactivation. After centrifugation at $12,000 \times g$ for $15 \min$ at $4{ }^{\circ} \mathrm{C}$, the supernatant was transferred to a new tube. The remaining sludge was re-extracted a further two times in the same manner, and the collected supernatants were combined. The crude extract was loaded onto a mini-column and desulfated by the addition of aryl sulfatase solution ( $75 \mu \mathrm{L}, 29$ units) to the column. The desulfation reaction was carried out overnight at ambient temperature, and then $0.5 \mathrm{~mL}$ of HPLC-grade water was used for elution of desulfo-glucosinolates. The solution was then filtered into a vial through a $0.45-\mu \mathrm{m}$ syringe filter. The LC conditions used followed those established in a previous study [34]. Desulfoglucosinolates were quantified according to their response factor, HPLC area, and an external sinigrin standard. The values represent the means \pm standard deviation of three biological replicates.

\subsection{Extraction of Phenylpropanoids from Brassica napus and HPLC Analysis}

Samples of dried sprout powder (100 mg) were extracted with $80 \%(\mathrm{v} / \mathrm{v})$ methanol and then sonicated for $1 \mathrm{~h}$ with vortexing every $20 \mathrm{~min}$ during the incubation. After centrifugation at 12,000 rpm for $15 \mathrm{~min}$, crude extracts were transferred to a new tube. The remaining sludge was re-extracted a further two times in the same manner. The collected solution was filtered through $0.45-\mu \mathrm{m}$ filters for subsequent HPLC analysis. The LC conditions used followed those established in a previous study [35]. Identification and quantification of phenolic compounds were carried out by comparison of retention times and spike tests, and corresponding calibration curves. The values represent the means \pm standard deviation of three biological replicates.

\subsection{Statistical Analysis}

Growth and HPLC data were statistically analyzed with Duncan's multiple range test at $p<0.05$ using Statistical Analysis System software (SAS, system 9.4, 2013; SAS Institute, Inc., Cary, NC, USA). Reported values represent the means \pm standard deviation of three biological replicates.

\section{Results}

\subsection{Sprout Length and Fresh Weight}

Different LEDs had a considerable effect on the shoot length and fresh weight of sprouts, with those of red light-irradiated sprouts being significantly higher than those of sprouts exposed to other LEDs (Figure 1). Specifically, the shoot lengths of red light-irradiated sprouts were 1.64-, 1.41-, and 1.81-fold higher and the fresh weights 1.44-, 1.34-, and 1.54-fold higher than those of spouts exposed to white, blue, and blue + red LEDs, respectively. In contrast, root length was not significantly different among the red, blue, white, and blue + red LED treatments. 

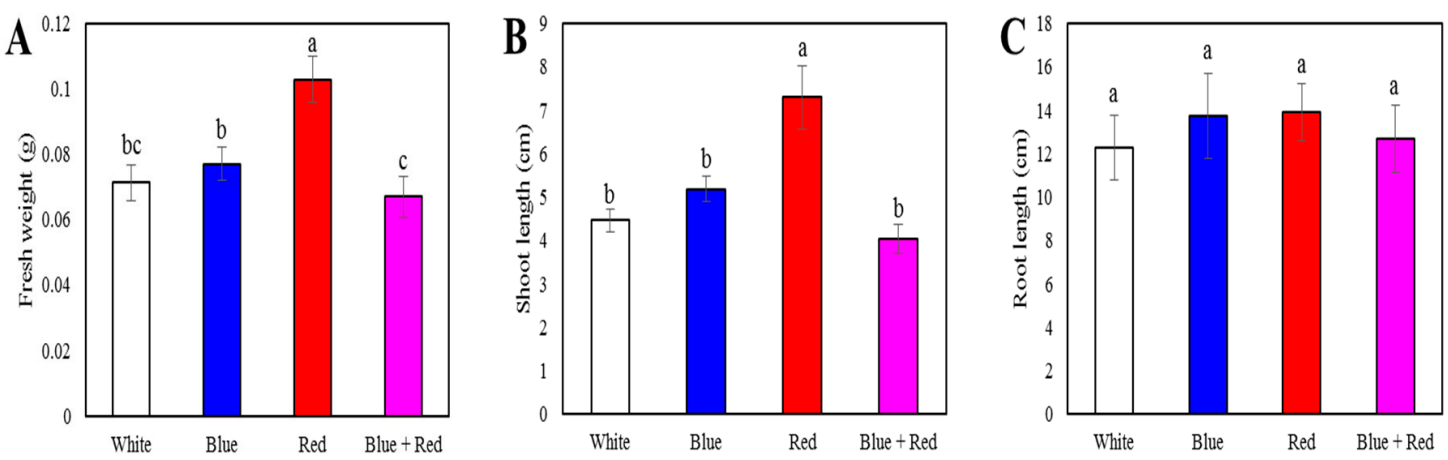

Figure 1. Growth of Brassica napus sprouts grown under different light-emitting diode (LED) lights (blue, white, red, and blue + red): (A) shoot length; (B) root length; and (C) fresh weight from 14 days. Each value is the mean of three biological replicates, and error bars indicate the standard deviation (SD). Different letters above bars indicate a significant difference $(p<0.05)$.

\subsection{Accumulation of Glucosinolates in Sprouts}

Glucosinolates were analyzed in B. napus sprouts grown under LED irradiation (Table 1). A total of 16 glucosinolates (one aromatic glucosinolate (gluconasturtiin), four indolic glucosinolates (glucobrassicin, 4-methoxyglucobrassicin, 4-hydroxyglucobrassicin, and neoglucobrassicin), and 11 aliphatic glucosinolates (sinigrin, glucoiberin, glucobrassicanapin, glucoraphanin, gluconapoleiferin, glucoalyssin, gluconapin, glucoerucin, glucoberteroin, glucoraphasatin, and progoitrin)) were detected and quantified in the sprouts of $B$. napus through comparison of retention times, HPLC areas, and response factors with respect to those of an external standard. The levels of total glucosinolates in the canola seedlings irradiated with the white, blue, and red LEDs were not significantly different $(19.32 \pm 0.13$, $20.69 \pm 0.05$, and $20.65 \pm 1.70 \mathrm{mg} / \mathrm{g}$ dry wt., respectively). Seedlings exposed to the blue + red LED light contained the lowest levels of total glucosinolates $(17.08 \pm 0.28 \mathrm{mg} / \mathrm{g}$ dry wt.). Among the individual glucosinolates, the levels of sinigrin, glucobrassicin, and 4-methoxy glucobrassicin were higher in sprouts exposed to red LED light, whereas seedlings grown under blue LED light contained the highest levels of glucoraphanin. Furthermore, higher levels of glucoalyssin and gluconapin were obtained in sprouts exposed to white and blue LED light.

Table 1. The accumulation of glucosinolates (mg/g dry wt.) in Brassica napus sprouts grown under different LED lights.

\begin{tabular}{ccccc}
\hline Glucosinolate & White & Blue & Red & Blue + Red \\
\hline Glucoiberin & $0.15 \pm 0.01 \mathrm{a} 1$ & $0.14 \pm 0.03 \mathrm{a}$ & $0.12 \pm 0.01 \mathrm{a}$ & $0.13 \pm 0.01 \mathrm{a}$ \\
Progoitrin & $9.38 \pm 0.12 \mathrm{~b}$ & $10.68 \pm 0.16 \mathrm{a}$ & $10.01 \pm 1.07 \mathrm{ab}$ & $7.70 \pm 0.17 \mathrm{c}$ \\
Glucoraphanin & $0.21 \pm 0.01 \mathrm{~b}$ & $0.25 \pm 0.01 \mathrm{a}$ & $0.22 \pm 0.03 \mathrm{~b}$ & $0.20 \pm 0.00 \mathrm{~b}$ \\
Sinigrin & $1.04 \pm 0.04 \mathrm{~b}$ & $0.82 \pm 0.00 \mathrm{c}$ & $1.60 \pm 0.14 \mathrm{a}$ & $1.00 \pm 0.02 \mathrm{~b}$ \\
Glucoalyssin & $0.07 \pm 0.01 \mathrm{a}$ & $0.07 \pm 0.00 \mathrm{a}$ & $0.05 \pm 0.01 \mathrm{~b}$ & $0.05 \pm 0.00 \mathrm{~b}$ \\
Gluconapoleiferin & $0.36 \pm 0.01 \mathrm{ab}$ & $0.39 \pm 0.03 \mathrm{a}$ & $0.34 \pm 0.05 \mathrm{ab}$ & $0.32 \pm 0.02 \mathrm{~b}$ \\
Gluconapin & $1.56 \pm 0.04 \mathrm{a}$ & $1.58 \pm 0.02 \mathrm{a}$ & $1.43 \pm 0.13 \mathrm{~b}$ & $1.18 \pm 0.01 \mathrm{c}$ \\
4-Hydroxy glucobrassicin & $1.89 \pm 0.07 \mathrm{a}$ & $1.78 \pm 0.12 \mathrm{a}$ & $1.58 \pm 0.06 \mathrm{~b}$ & $1.91 \pm 0.05 \mathrm{a}$ \\
Glucobrassicanapin & $0.14 \pm 0.00 \mathrm{a}$ & $0.13 \pm 0.00 \mathrm{a}$ & $0.12 \pm 0.01 \mathrm{a}$ & $0.11 \pm 0.00 \mathrm{~b}$ \\
Glucoerucin & $0.03 \pm 0.00 \mathrm{ab}$ & $0.04 \pm 0.00 \mathrm{a}$ & $0.03 \pm 0.00 \mathrm{~b}$ & $0.05 \pm 0.01 \mathrm{a}$ \\
Glucoraphasatin & $0.03 \pm 0.00 \mathrm{a}$ & $0.04 \pm 0.00 \mathrm{a}$ & $0.04 \pm 0.00 \mathrm{a}$ & $0.04 \pm 0.00 \mathrm{a}$ \\
Glucobrassicin & $1.26 \pm 0.03 \mathrm{~b}$ & $1.07 \pm 0.04 \mathrm{c}$ & $1.36 \pm 0.04 \mathrm{a}$ & $1.29 \pm 0.02 \mathrm{~b}$ \\
4-Methoxy glucobrassicin & $0.88 \pm 0.03 \mathrm{c}$ & $0.96 \pm 0.05 \mathrm{~b}$ & $1.05 \pm 0.02 \mathrm{a}$ & $0.91 \pm 0.02 \mathrm{c}$ \\
Glucoberteroin & $0.03 \pm 0.00 \mathrm{a}$ & $0.03 \pm 0.00 \mathrm{a}$ & $0.04 \pm 0.01 \mathrm{a}$ & $0.03 \pm 0.00 \mathrm{a}$ \\
Gluconasturtiin & $0.16 \pm 0.00 \mathrm{ab}$ & $0.15 \pm 0.01 \mathrm{ab}$ & $0.17 \pm 0.02 \mathrm{a}$ & $0.14 \pm 0.00 \mathrm{~b}$ \\
Neoglucobrassicin & $2.12 \pm 0.10 \mathrm{~b}$ & $2.55 \pm 0.01 \mathrm{a}$ & $2.54 \pm 0.17 \mathrm{a}$ & $2.07 \pm 0.04 \mathrm{~b}$ \\
\hline Total & $19.32 \pm 0.13 \mathrm{a}$ & $20.69 \pm 0.05 \mathrm{a}$ & $20.65 \pm 1.70 \mathrm{a}$ & $17.08 \pm 0.28 \mathrm{~b}$ \\
\hline
\end{tabular}

${ }^{1}$ Different letters in the same row indicate a significant difference $(p<0.05)$. 


\subsection{Accumulation of Phenolics in Sprouts}

A total of eight phenolic compounds (four phenolic acids (chlorogenic, caffeic, sinapic, and benzoic acid) and four flavonoids (rutin, catechin, epicatechin, and quercetin)) were detected and quantified in the seedlings of B. napus through HPLC comparison of retention times, spike tests, and external standard calibration curves (Table 2). The highest level of total phenolic compounds was obtained in blue light-radiated sprouts $(3.81 \pm 0.08 \mathrm{mg} / \mathrm{g}$ dry wt.), which was 1.33 times higher than the lowest level obtained from red light-radiated sprouts $(2.87 \pm 0.05 \mathrm{mg} / \mathrm{g}$ dry wt.). Notably, the sprouts exposed to blue LED lights showed the highest levels of benzoic acid, (+)-catechin, caffeic acid, and (-)-epicatechin. In contrast, the highest levels of sinapic acid and rutin were obtained in red light-irradiated sprouts, whereas the levels of chlorogenic acid and quercetin were higher in seedlings exposed to white and blue LED lights.

Table 2. The accumulation of phenolics (mg/g dry wt.) in Brassica napus sprouts grown under different LED lights.

\begin{tabular}{cccccc}
\hline Class & Compound & White & Blue & Red & Blue + Red \\
\hline \multirow{3}{*}{ Phenolic acid } & Caffeic acid & $0.41 \pm 0.01 \mathrm{c}$ & $0.55 \pm 0.01 \mathrm{a}$ & $0.40 \pm 0.02 \mathrm{c}$ & $0.46 \pm 0.02 \mathrm{~b}$ \\
& Chlorogenic acid & $0.14 \pm 0.01 \mathrm{a}$ & $0.15 \pm 0.01 \mathrm{a}$ & $0.07 \pm 0.00 \mathrm{~b}$ & $0.15 \pm 0.04 \mathrm{a}$ \\
& Sinapic acid & $0.14 \pm 0.00 \mathrm{a}$ & $0.08 \pm 0.01 \mathrm{~b}$ & $0.10 \pm 0.01 \mathrm{~b}$ & $0.09 \pm 0.01 \mathrm{~b}$ \\
\hline \multirow{2}{*}{ Catechin } & $\begin{array}{c}\text { (-)-Epicatechin } \\
\text { (+)-Catechin }\end{array}$ & $0.44 \pm 0.07 \mathrm{~b}$ & $1.77 \pm 0.05 \mathrm{a}$ & $1.26 \pm 0.04 \mathrm{c}$ & $1.47 \pm 0.11 \mathrm{~b}$ \\
& Benzoic acid & $\mathrm{ND}^{2}$ & $0.65 \pm 0.01 \mathrm{a}$ & $0.49 \pm 0.02 \mathrm{~b}$ & $0.44 \pm 0.07 \mathrm{~b}$ \\
\hline \multirow{2}{*}{ Organic acid } & Rutin & $0.30 \pm 0.00 \mathrm{a}$ & $0.23 \pm 0.00 \mathrm{~d}$ & $0.28 \pm 0.01 \mathrm{~b}$ & $0.25 \pm 0.01 \mathrm{c}$ \\
\multirow{2}{*}{ Flavonoid } & Quercetin & $0.29 \pm 0.00 \mathrm{a}$ & $0.29 \pm 0.00 \mathrm{a}$ & $0.28 \pm 0.00 \mathrm{~b}$ & $0.28 \pm 0.00 \mathrm{~b}$ \\
\hline & Total & $3.29 \pm 0.04 \mathrm{~b}$ & $3.81 \pm 0.08 \mathrm{a}$ & $2.87 \pm 0.05 \mathrm{~d}$ & $3.14 \pm 0.04 \mathrm{c}$ \\
\hline
\end{tabular}

${ }^{1}$ Different letters in the same row indicate a significant difference $(p<0.05) .{ }^{2} \mathrm{ND}$, not detected.

\section{Discussion}

Plant development, morphogenesis, growth, and secondary metabolite synthesis are significantly affected by light quality and intensity $[29,36]$. In the current study, red LED light was found to be suitable for sprout growth. Our findings are consistent with those obtained in previous studies. McNellis and Deng [37], for example, demonstrated that red light induces cotyledon expansion and hypocotyl elongation and that blue light induces cotyledon expansion and suppresses hypocotyl elongation in Arabidopsis seedlings. Similarly, Miyashita et al. [38] reported that blue light inhibited stalk elongation, whereas red light significantly enhanced elongation in pelargonium plantlets. Furthermore, red light irradiation for 4 days has been shown to increase the leaf area and stem length of pea seedlings compared with seedlings exposed to white light [39], and Thew et al. [40] reported that red LED light irradiation promoted significant increases in the shoot length and fresh weight of Fagopyrum tataricum sprouts compared with blue and white LED lights.

Brassica vegetables are a rich source of plant phenolics and glucosinolates. In the current study, we detected and quantified 16 glucosinolates and eight phenolic compounds in canola sprouts irradiated with different LEDs. These results are consistent with those of previous studies that have analyzed progoitrin, gluconapin, 4-hydroxyglucobrassicin, glucobrassicanapin, glucobrassicin, and gluconasturtiin in canola seed [13-15], and glucoiberin, progoitrin, sinigrin, glucoraphanin, gluconapoleiferin, gluconapin, 4-hydroxiglucobrassicin, glucobrassicanapin, glucobrassicin, gluconasturtiin, and neoglucobrassicin in leaf rape (B. napus var. pabularia) [41]. Furthermore, quercetin, (-)-epicatechin, sinapic acid, and caffeic acid have previously been identified in the seeds of B. napus [42].

According to the results of our phenolic compound analyses, irradiation with blue LEDs improves the production of most phenolics, including (+)-catechin, caffeic acid, and (-)-epicatechin. With respect to glucosinolate contents of the canola sprouts irradiated with different LEDs, sprouts grown under 
blue, red, and white LEDs showed higher levels of glucosinolates compared with blue + red LEDs. These results are consistent with the findings of previous studies. Kim et al. [6], for example, reported that exposure to blue LED light promoted a high production of most phenolics in Chinese cabbage seedlings after irradiation for 12 days, whereas Ghimire et al. [43] reported a marked increase in the accumulation of phenolics in ginseng adventitious roots. Similarly, Thew et al. [40] demonstrated that exposure to blue LED light irradiation induced upregulated phenylpropanoid biosynthesis in tartary buckwheat sprouts and production of phenolics in cowpea sprouts [44]. Additionally, exposure to blue LED light enhanced production of phenolic acids in the shoot cultures of Aronia melanocarpa, Aronia arbutifolia, and Aronia prunifolia [45] as well as chlorogenic acid in callus of Peucedanum japonicum Thunb. [46] and total phenolic contents in callus of Ocimum bassilicum [47].

Furthermore, exposure to blue LED light has been shown to lead to a pronounced enhancement of carotenoid biosynthesis in citrus juice sacs in vitro [48] and in the Chinese skullcap callus [49], as well as the enhanced production of glucosinolates in broccoli sprouts, compared with blue + red LED treatment [50]. Red LEDs have been reported to promote higher levels of phenolic compounds in Myrtus communis L. in vitro [51] and carotenoid synthesis in the flavedo of citrus fruits [52], whereas white LEDs have been found to enhance carotenoid production in the sprouts of tartary buckwheat [53]. Moreover, is has been demonstrated that the production of phenolics does not differ significantly in sprouts of common buckwheat (cv. Kitawase) and tartary buckwheat (cv. Hokkai T8) exposed to blue, red, and blue + red LEDs [54], whereas fluorescent lights have been reported to increase the levels of ginsenoside-Rg1 and ginsenoside-Rb1 in Panax vietnamensis plantlets relative to irradiation with diverse types of LEDs [55]. In contrast, compared with light exposure, dark conditions have been found to decrease glucosinolate biosynthesis in Chinese cabbage seedlings [56].

On the basis of the findings of the present and previous studies, it appears that the influence of different light sources and wavelengths on the production of natural products might be dependent on plant species, cells, tissues, and organs. With respect to B. napus sprouts, however, the results of the present study indicate that blue LED lights are the optimal light source for the production of glucosinolates and phenolics.

Author Contributions: S.U.P. and J.-W.L. designed the experiments and analyzed the data. C.H.P., N.S.K., J.S.P., and S.Y.L performed the experiments and analyzed the data. C.H.P. and N.S.K wrote the manuscript. All authors read and approved the final manuscript.

Funding: This research was supported by Golden Seed Project (213006051WTE11) funded by Ministry of Agriculture, Food and Rural Affairs (MAFRA), Ministry of Oceans and Fisheries (MOF), Rural Development Administration (RDA) and Korea Forest Service (KFS), Republic of Korea.

Acknowledgments: This work was carried out with the support of "Cooperative Research Program for Agriculture Science and Technology Development (Project No. PJ01347202)" Rural Development Administration, Republic of Korea.

Conflicts of Interest: The authors declare no conflict of interest.

\section{References}

1. Marton, M.; Mandoki, Z.; Csapo-Kiss, Z.; Csapo, J. The role of sprouts in human nutrition. A review. Acta Univ. Sapientiae 2010, 3, 81-117.

2. Cartea, M.E.; Francisco, M.; Soengas, P.; Velasco, P. Phenolic compounds in Brassica vegetables. Molecules 2010, 16, 251-280. [CrossRef]

3. Fernandez-Orozco, R.; Piskula, M.K.; Zielinski, H.; Kozlowska, H.; Frias, J.; Vidal-Valverde, C. Germination as a process to improve the antioxidant capacity of Lupinus angustifolius L. var. Zapaton. Eur. Food Res. Technol. 2006, 223, 495. [CrossRef]

4. Shapiro, T.A.; Fahey, J.W.; Wade, K.L.; Stephenson, K.K.; Talalay, P. Chemoprotective glucosinolates and isothiocyanates of broccoli sprouts: Metabolism and excretion in humans. Cancer Epidemiol. Biomark. Prev. 2001, 10, 501-508.

5. Baenas, N.; Ferreres, F.; García-Viguera, C.; Moreno, D.A. Radish sprouts-Characterization and elicitation of novel varieties rich in anthocyanins. Food Res. Int. 2015, 69, 305-312. [CrossRef] 
6. Kim, Y.J.; Kim, Y.B.; Li, X.; Choi, S.R.; Park, S.; Park, J.S.; Lim, Y.P.; Park, S.U. Accumulation of phenylpropanoids by white, blue, and red light irradiation and their organ-specific distribution in Chinese cabbage (Brassica rapa ssp. pekinensis). J. Agric. Food Chem. 2015, 63, 6772-6778. [CrossRef] [PubMed]

7. Tuan, P.A.; Park, N.I.; Park, W.T.; Kim, Y.B.; Kim, J.K.; Lee, J.; Lee, S.-H.; Yang, T.-J.; Park, S.U. Carotenoids accumulation and expression of carotenogenesis genes during seedling and leaf development in Chinese cabbage ('Brassica rapa subsp. pekinensis'). Plant Omics 2012, 5, 143-148.

8. Kristal, A.R.; Lampe, J.W. Brassica vegetables and prostate cancer risk: A review of the epidemiological evidence. Nutr. Cancer 2002, 42, 1-9. [CrossRef] [PubMed]

9. USDA. Oilseeds: World Markets and Trade; United States Department of Agriculture, Foreing Agricultural Service: Washington, DC, USA, 2018; pp. 1-40.

10. Kumar, A.; Premi, O.; Thomas, L. Rapeseed-Mustard Cultivation in India-An Overview; National Research Centre on Canolaseed-Mustard: Bharatpur, India, 2008.

11. Szydłowska-Czerniak, A.; Trokowski, K.; Karlovits, G.R.; Szłyk, E. Determination of antioxidant capacity, phenolic acids, and fatty acid composition of rapeseed varieties. J. Agric. Food Chem. 2010, 58, 7502-7509. [CrossRef]

12. Khattab, R.; Eskin, M.; Aliani, M.; Thiyam, U. Determination of sinapic acid derivatives in canola extracts using high-performance liquid chromatography. J. Am. Oil Chem. Soc. 2010, 87, 147-155. [CrossRef] [PubMed]

13. Brown, P.; Morra, M. Hydrolysis products of glucosinolates in Brassica napus tissues as inhibitors of seed germination. Plant Soil 1996, 181, 307-316. [CrossRef]

14. Vierheilig, H.; Bennett, R.; Kiddle, G.; Kaldorf, M.; Ludwig-Müller, J. Differences in glucosinolate patterns and arbuscular mycorrhizal status of glucosinolate-containing plant species. New Phytol. 2000, 146, 343-352. [CrossRef]

15. Yasumoto, S.; Matsuzaki, M.; Hirokane, H.; Okada, K. Glucosinolate content in rapeseed in relation to suppression of subsequent crop. Plant Prod. Sci. 2010, 13, 150-155. [CrossRef]

16. Ludwig-Müller, J.; Schubert, B.; Pieper, K.; Ihmig, S.; Hilgenberg, W. Glucosinolate content in susceptible and resistant Chinese cabbage varieties during development of clubroot disease. Phytochemistry 1997, 44, 407-414. [CrossRef]

17. Vaughn, S.F. Glucosilates as natural pesticides. In Biologically Active Natural Products: Agrochemicals; CRC Press: Boca Raton, FL, USA, 1999; pp. 81-91.

18. Fahey, J.W.; Zalcmann, A.T.; Talalay, P. The chemical diversity and distribution of glucosinolates and isothiocyanates among plants. Phytochemistry 2001, 56, 5-51. [CrossRef]

19. Heber, D. Vegetables, fruits and phytoestrogens in the prevention of diseases. J. Postgrad. Med. 2004, 50, 145-149. [PubMed]

20. Higdon, J.V.; Delage, B.; Williams, D.E.; Dashwood, R.H. Cruciferous vegetables and human cancer risk: Epidemiologic evidence and mechanistic basis. Pharmacol. Res. 2007, 55, 224-236. [CrossRef]

21. Dixon, R.A.; Paiva, N.L. Stress-induced phenylpropanoid metabolism. Plant Cell 1995, 7, $1085-1097$. [CrossRef]

22. Bennett, R.N.; Wallsgrove, R.M. Secondary metabolites in plant defence mechanisms. New Phytol. 1994, 127, 617-633. [CrossRef]

23. Ullah, M.F.; Khan, M.W. Food as medicine: Potential therapeutic tendencies of plant derived polyphenolic compounds. Asian Pac. J. Cancer Prev. 2008, 9, 187-196.

24. Critchfield, J.W.; Butera, S.T.; Folks, T.M. Inhibition of HIV activation in latently infected cells by flavonoid compounds. AIDS Res. Hum. Retroviruses 1996, 12, 39-46. [CrossRef] [PubMed]

25. Cai, Y.; Luo, Q.; Sun, M.; Corke, H. Antioxidant activity and phenolic compounds of 112 traditional Chinese medicinal plants associated with anticancer. Life Sci. 2004, 74, 2157-2184. [CrossRef]

26. Fang, S.-C.; Hsu, C.-L.; Yen, G.-C. Anti-inflammatory effects of phenolic compounds isolated from the fruits of Artocarpus heterophyllus. J. Agric. Food Chem. 2008, 56, 4463-4468. [CrossRef] [PubMed]

27. Ferrazzano, G.F.; Amato, I.; Ingenito, A.; De Natale, A.; Pollio, A. Anti-cariogenic effects of polyphenols from plant stimulant beverages (cocoa, coffee, tea). Fitoterapia 2009, 80, 255-262. [CrossRef] [PubMed]

28. Cook, N.; Samman, S. Flavonoids-Chemistry, metabolism, cardioprotective effects, and dietary sources. J. Nutr. Biochem. 1996, 7, 66-76. [CrossRef] 
29. Fukuda, N.; Kobayashi, M.; Ubukawa, M.; Takayanagi, K.; Sase, S. Effects of light quality, intensity and duration from different artificial light sources on the growth of petunia (Petunia $\times$ hybrida Vilm.). J. Jpn. Soc. Hortic. Sci. 2002, 71, 509-516. [CrossRef]

30. Yeh, N.; Chung, J.-P. High-brightness LEDs-Energy efficient lighting sources and their potential in indoor plant cultivation. Renew. Sust. Energ. Rev. 2009, 13, 2175-2180. [CrossRef]

31. Johkan, M.; Shoji, K.; Goto, F.; Hashida, S.-N.; Yoshihara, T. Blue light-emitting diode light irradiation of seedlings improves seedling quality and growth after transplanting in red leaf lettuce. HortScience 2010, 45, 1809-1814. [CrossRef]

32. International Standards Organization (ISO). Part 1: Method Using High Performance Liquid Chromatography. In Rapeseed: Determination of Glucosinolates Content, (ISO 9167-1); ISO: Geneva, Switzerland, 1992; pp. 1-9.

33. Al-Dhabi, N.A.; Arasu, M.V.; Kim, S.J.; RomijUddin, M.; Park, W.T.; Lee, S.Y.; Park, S.U. Methyl Jasmonate-and Light-Induced Glucosinolate and Anthocyanin Biosynthesis in Radish Seedlings. Nat. Prod. Commun. 2015, 10, 1211-1214.

34. Kim, S.-J.; Park, W.T.; Uddin, M.R.; Kim, Y.B.; Nam, S.Y.; Jho, K.H.; Park, S.U. Glucosinolate biosynthesis in hairy root cultures of broccoli (Brassica oleracea var. italica). Nat. Prod. Commun. 2013, 8, 217-220. [CrossRef]

35. Park, C.H.; Yeo, H.J.; Park, Y.J.; Morgan, A.; Valan Arasu, M.; Al-Dhabi, N.A.; Park, S.U. Influence of indole-3-acetic acid and gibberellic acid on phenylpropanoid accumulation in common buckwheat (Fagopyrum esculentum Moench) sprouts. Molecules 2017, 22, 374. [CrossRef] [PubMed]

36. Nishimura, T.; Zobayed, S.M.; Kozai, T.; Goto, E. Medicinally important secondary metabolites and growth of Hypericum perforatum L. plants as affected by light quality and intensity. Environ. Control Biol. 2007, 45, 113-120. [CrossRef]

37. McNellis, T.W.; Deng, X.-W. Light control of seedling morphogenetic pattern. Plant Cell 1995, 7, $1749-1761$. [CrossRef] [PubMed]

38. Miyashita, Y.; Kitaya, Y.; Kozai, T.; Kimura, T. Effects of red and far-red light on the growth and morphology of potato plantlets in vitro: Using light emitting diode as a light source for micropropagation. Acta Hortic. 1994, 393, 189-194. [CrossRef]

39. Wu, M.-C.; Hou, C.-Y.; Jiang, C.-M.; Wang, Y.-T.; Wang, C.-Y.; Chen, H.-H.; Chang, H.-M. A novel approach of LED light radiation improves the antioxidant activity of pea seedlings. Food Chem. 2007, 101, 1753-1758. [CrossRef]

40. Thwe, A.A.; Kim, Y.B.; Li, X.; Seo, J.M.; Kim, S.-J.; Suzuki, T.; Chung, S.-O.; Park, S.U. Effects of light-emitting diodes on expression of phenylpropanoid biosynthetic genes and accumulation of phenylpropanoids in Fagopyrum tataricum sprouts. J. Agric. Food Chem. 2014, 62, 4839-4845. [CrossRef]

41. Velasco, P.; Francisco, M.; Moreno, D.A.; Ferreres, F.; García-Viguera, C.; Cartea, M.E. Phytochemical fingerprinting of vegetable Brassica oleracea and Brassica napus by simultaneous identification of glucosinolates and phenolics. Phytochem. Anal. 2011, 22, 144-152. [CrossRef]

42. Jiang, J.; Shao, Y.; Li, A.; Lu, C.; Zhang, Y.; Wang, Y. Phenolic composition analysis and gene expression in developing seeds of yellow-and black-seeded Brassica napus. J. Integr. Plant Biol. 2013, 55, 537-551. [CrossRef]

43. Ghimire, B.K.; Lee, J.G.; Yoo, J.H.; Kim, J.K.; Yu, C.Y. The Influence of Light-Emitting Diodes (LEDs) on the Growth, Antioxidant Activities, and Metabolites in Adventitious Root of Panax ginseng CA Meyer. In Light Emitting Diodes for Agriculture, 1st ed.; Springer: Singapore, 2017; pp. 259-272.

44. Yeo, H.J.; Park, C.H.; Lee, K.B.; Kim, J.K.; Park, J.S.; Lee, J.W.; Park, S.U. Metabolic Analysis of Vigna unguiculata Sprouts Exposed to Different Light-Emitting Diodes. Nat. Prod. Commun. 2018, 13, 1349-1354.

45. Szopa, A.; Starzec, A.; Ekiert, H. The importance of monochromatic lights in the production of phenolic acids and flavonoids in shoot cultures of Aronia melanocarpa, Aronia arbutifolia and Aronia $\times$ prunifolia. J. Photochem. Photobiol. B Biol. 2018, 179, 91-97. [CrossRef]

46. Chen, C.-C.; Agrawal, D.C.; Lee, M.-R.; Lee, R.-J.; Kuo, C.-L.; Wu, C.-R.; Tsay, H.-S.; Chang, H.-C. Influence of LED light spectra on in vitro somatic embryogenesis and LC-MS analysis of chlorogenic acid and rutin in Peucedanum japonicum Thunb.: A medicinal herb. Bot. Stud. 2016, 57, 9. [CrossRef] [PubMed]

47. Nadeem, M.; Abbasi, B.H.; Younas, M.; Ahmad, W.; Zahir, A.; Hano, C. LED-enhanced biosynthesis of biologically active ingredients in callus cultures of Ocimum basilicum. J. Photochem. Photobiol. B: Biol. 2019, 190, 172-178. [CrossRef] 
48. Zhang, L.; Ma, G.; Kato, M.; Yamawaki, K.; Takagi, T.; Kiriiwa, Y.; Ikoma, Y.; Matsumoto, H.; Yoshioka, T.; Nesumi, H. Regulation of carotenoid accumulation and the expression of carotenoid metabolic genes in citrus juice sacs in vitro. J. Exp. Bot. 2011, 63, 871-886. [CrossRef] [PubMed]

49. Tuan, P.A.; Park, C.H.; Park, W.T.; Kim, Y.B.; Kim, Y.J.; Chung, S.O.; Kim, J.K.; Park, S.U. Expression levels of carotenoid biosynthetic genes and carotenoid production in the callus of Scutellaria baicalensis exposed to white, blue, and red light-emitting diodes. Appl. Biol. Chem. 2017, 60, 591-596. [CrossRef]

50. Kopsell, D.A.; Sams, C.E. Increases in shoot tissue pigments, glucosinolates, and mineral elements in sprouting broccoli after exposure to short-duration blue light from light emitting diodes. J. Am. Soc. Hort. Sci. 2013, 138, 31-37. [CrossRef]

51. Cioć, M.; Szewczyk, A.; Żupnik, M.; Kalisz, A.; Pawłowska, B. LED lighting affects plant growth, morphogenesis and phytochemical contents of Myrtus communis L. in vitro. Plant Cell Tissue Organ Cult. 2018, 132, 433-447. [CrossRef]

52. Ma, G.; Zhang, L.; Kato, M.; Yamawaki, K.; Kiriiwa, Y.; Yahata, M.; Ikoma, Y.; Matsumoto, H. Effect of blue and red LED light irradiation on $\beta$-cryptoxanthin accumulation in the flavedo of citrus fruits. J. Agric. Food Chem. 2011, 60, 197-201. [CrossRef]

53. Tuan, P.A.; Thwe, A.A.; Kim, Y.B.; Kim, J.K.; Kim, S.-J.; Lee, S.; Chung, S.-O.; Park, S.U. Effects of white, blue, and red light-emitting diodes on carotenoid biosynthetic gene expression levels and carotenoid accumulation in sprouts of tartary buckwheat (Fagopyrum tataricum Gaertn.). J. Agric. Food Chem. 2013, 61, 12356-12361. [CrossRef]

54. Lee, S.-W.; Seo, J.M.; Lee, M.-K.; Chun, J.-H.; Antonisamy, P.; Arasu, M.V.; Suzuki, T.; Al-Dhabi, N.A.; Kim, S.-J. Influence of different LED lamps on the production of phenolic compounds in common and Tartary buckwheat sprouts. Ind. Crops Prod. 2014, 54, 320-326. [CrossRef]

55. Nhut, D.T.; Huy, N.P.; Tai, N.T.; Nam, N.B.; Luan, V.Q.; Hien, V.T.; Tung, H.T.; Vinh, B.T.; Luan, T.C. Light-emitting diodes and their potential in callus growth, plantlet development and saponin accumulation during somatic embryogenesis of Panax vietnamensis Ha et Grushv. Biotechnol. Biotechnol. Equip. 2015, 29, 299-308. [CrossRef]

56. Kim, Y.B.; Chun, J.-H.; Kim, H.R.; Kim, S.-J.; Lim, Y.P.; Park, S.U. Variation of glucosinolate accumulation and gene expression of transcription factors at different stages of Chinese cabbage seedlings under light and dark conditions. Nat. Prod. Commun. 2014, 9, 533-537. [PubMed] 